\title{
PHYTOSOCIOLOGY OF WEEDS IN MILLET UNDER DIFFERENT SOIL MANAGEMENTS IN SAVANNA SUL-MATO-GROSSENSE
}

\author{
FITOSSOCIOLOGIA DE PLANTAS DANINHAS EM MILHETO SOB DIFERENTES \\ MANEJOS DO SOLO NO CERRADO SUL-MATO-GROSSENSE
}

\begin{abstract}
Paulo Eduardo TEODORO ${ }^{1}$; Larissa Pereira RIBEIRO ${ }^{2}$; Caio Cezar Guedes CORRÊA ${ }^{1}$; Roque Apolinário Alves da LUZ JÚNIOR ${ }^{3}$; Mariana Conceição de SOUZA ${ }^{1}$; Mayara dos Santos SIMÕES ${ }^{1}$; Francisco Eduardo TORRES ${ }^{4}$

1. Aluno do Programa de Pós-Graduação Stricto Sensu em Agronomia - área de concentração: Produção Vegetal da Universidade Estadual de Mato Grosso do Sul, Unidade Universitária de Aquidauana (UEMS/UUA), Aquidauana, MS, Brasil. eduteodoro@ hotmail.com; 2. Discente do curso de Agronomia, UEMS/UUA, Aquidauana, MS, Brasil; 3. Engenheiro Agrônomo da Empresa Dow AgroSciences; 4. Professor Dr. do curso de Agronomia e do Programa de Pós-Graduação Stricto Sensu em Agronomia - área de concentração: Produção Vegetal da UEMS/UUA.
\end{abstract}

\begin{abstract}
The millet crop in recent decades has shown an increase in planted area, mainly in the Cerrado region. However, there are few studies related to the management and phytossociology of weeds in this culture. Thus, the objective of this research was to perform a phytosociological survey in millet under different soil managements in Savanna Sul-Mato-Grossense region. The experiment was conducted in the experimental area of Universidade Estadual de Mato Grosso do Sul - Unit of Aquidauana (UEMS/UUA), in Aquidauana-MS. The area is cultivated to five years with soybeans in first crop and corn in second. The experimental design was randomized complete block in a split-plot design consisting of four blocks with four replications. In the plots were used soil preparation systems (minimum tillage and no-tillage) and in the subplots was utilized the nitrogen fertilization at $50 \mathrm{~kg} \mathrm{ha}^{-1}$ and absence of nitrogen on millet at 25 days after emergence (DAE). Were evaluated the parameters number of species (NS), total number and dry mass of weeds (TN and DMW, respectively), dry mass of millet (DMM) and frequency (F), density (D), abundance (A) and Importance Value (IV) of weeds. The no-tillage system provided greater dry mass of weeds, whereas the nitrogen resulted in a smaller total number of weeds (TN). Cynodon dactylon and Commelina benghalensis were the most predominant species on area.
\end{abstract}

KEYWORDS: Nitrogen fertilization. Pennisetum glaucum L. Tillage. Weeds identification.

\section{INTRODUCTION}

The millet (Pennisetum glaucum L.) is an annual grass that has been showing in the last decades an increase in the planted area, especially in Savanna regions, both by enormous potential of soil cover offered for practice of no-tillage, as for their fodder use in livestock (PEREIRA FILHO et al., 2003). According to Torres et al. (2014), this crop growth in the Brazilian Savanna is due to its high adaptability to prolonged drought and less fertile soils, typical conditions of this region.

According to Albuquerque et al. (2012), the knowledge of species diversity is important for understanding the dynamics of weeds regarding to those crops grown in different grown seasons. For this purpose are used evaluation methods established by phytosociology which consists in the study of plant communities to establish a comprehensive overview of the composition and distribution of plant species in an area (GUGLIERICAPORAL et al., 2010).
The tillage systems, through its differentiated effects on weeds, can modify the community's botanical composition (JAKELAITIS et al., 2003). Godoy et al. (1995), report that the populations composition of weeds in an agroecosystem is a reflection of its soil and climate characteristics and agronomic practices, such as crop management (tillage, no-tillage and minimum tillage).

There are several studies about phytosociological surveys in the crops, as in sugarcane (OLIVEIRA; FREITAS, 2008; KUVA et al., 2000), maize (ALBUQUERQUE et al., 2013; JAKELAITIS et al., 2003) and cassava (CARDOSO et al., 2013; AZEVÊDO et al., 2000; GUGLIERICAPORAL et al., 2009). However, there are few studies of phytosociology of weeds to millet.

Under the hypothesis that the nitrogen fertilizer and soil managements promotes distinct behaviors in the incidence of weeds, the aim of this study was to conduct a phytosociological survey in millet under different soil managements in Savanna Sul-Mato-Grossense. 


\section{MATERIAL AND METHODS}

The experiment was conducted in the experimental area of Universidade Estadual de Mato Grosso do Sul - Aquidauana Unit (UEMS/UUA), in Aquidauana-MS. The region is located in the Savanna biome, comprising the geographic coordinates $20^{\circ} 27^{\prime} \mathrm{S}$ and $55^{\circ} 40^{\circ} \mathrm{W}$, with an average altitude of $170 \mathrm{~m}$ (TORRES et al., 2014).

The soil was classified as Ultisol sandy loam texture (EMBRAPA, 2013), with the following chemical characteristics in the layer $0-$ $0.20 \mathrm{~m}: \mathrm{pH}\left(\mathrm{H}_{2} \mathrm{O}\right)=6.2 ; \mathrm{Al}$ exchangeable $\left(\mathrm{cmol}_{\mathrm{c}}\right.$ $\left.\mathrm{dm}^{-3}\right)=0.0 ; \mathrm{Ca}+\mathrm{Mg}\left(\mathrm{cmol}_{\mathrm{c}} \mathrm{dm}^{-3}\right)=4.31 ; \mathrm{P}_{\text {resine }}(\mathrm{mg}$ $\left.\mathrm{dm}^{-3}\right)=41.3 ; \mathrm{K}\left(\mathrm{cmol}_{\mathrm{c}} \mathrm{dm}^{-3}\right)=0.2 ;$ Organic matter $\left(\mathrm{g} \mathrm{dm}^{-3}\right)=19.7 ; \mathrm{V}(\%)=45.0 ; \mathrm{m}(\%)=0.0 ;$ Sum of bases $\left(\mathrm{cmol}_{\mathrm{c}} \mathrm{dm}^{-3}\right)=4.51$; cation exchange capacity (or CEC) $\left(\mathrm{cmol}_{\mathrm{c}} \mathrm{dm}^{-3}\right)=5.1$. The climate of the region, according to the classification described by Köppen-Geiger, is Aw with annual rainfall of 1200 $\mathrm{mm}$ and maximum and minimum temperatures of 26.1 and $28.2^{\circ} \mathrm{C}$, respectively.

The experimental design was a randomized complete block in a split-plot design consisting of four blocks with four replications. In the plots was used the soil preparation systems (minimum tillage and no-tillage). In the last five years was cultivated soybean and maize in summer and winter, respectively. In the subplots was utilized the presence or absence of nitrogen on millet at 25 days after emergence (DAE). Each sub-plot consisted of seven lines of $5 \mathrm{~m}$ in length. Nitrogen was used under urea form $(45 \% \mathrm{~N})$ by applying $50 \mathrm{~kg} \mathrm{ha}^{-1} \mathrm{~N}$ in continuous bead laterally to the plant row.

To deploy the different soil managements for cultivation of millet, the herbicide application was performed with active ingredient glyphosate $720 \mathrm{SC}$ at $1.00 \mathrm{~kg} \mathrm{ha}^{-1}$. Scarification was carried out at $30 \mathrm{~cm}$ depth and two graders disking (24') in plots relating to minimum tillage. The millet sowing was carried out with simple seeder using spacing $0.45 \mathrm{~m}$ and density of 15 plants $\mathrm{m}^{-1}$ linear.

At 35 DAE of millet (VINCENSI et al., 2011), sampling an area of $1.0 \mathrm{~m}^{2}$ per subplot, were determined the number of species (NS), total number of weeds $(\mathrm{TN})$, dry mass of weeds (DMW) and dry mass of millet (DMM) per $\mathrm{m}^{2}$. These parameters were subjected to analysis of variance and the averages were compared by t-test using the statistical software Sisvar (FERREIRA, 2011).

The species identification occurred by comparison with specialized bibliographies. The phytosociological analysis was based on the methodology proposed by Braun-Blanquet (1979), where the frequency, density and abundance for each species were established (Table 1).

Table 1. Description of the evaluated characteristics, formulas and evaluation method for the phytosociological survey based on the methodology proposed by Braun-Blanquet (1979).

\begin{tabular}{cc}
\hline Characteristics & Method \\
\hline Frequency (F) & Number of releases that contain the species / Total number of releases \\
Density (D) & Total number of individuals per species/Total area collected \\
Abundance (A) & Total number of individuals per species / $\mathrm{N}^{\circ}$ of releases that contain the \\
& species \\
Relative Frequency (RF) & (Species frequency $\times 100) /$ Total frequency of all species \\
Relative Density (RD) & (Species density $\times 100) /$ Total density of all species \\
Relative Abundance (RA) & (Species abundance $\times 100) / T o t a l$ abundance of all species \\
IV $^{1}$ & $\mathrm{RF}+\mathrm{RD}+\mathrm{RA}$ \\
\hline
\end{tabular}

IImportance Value

The frequency was transformed into classes according to tables proposed by Raunkiaer (1934) (Table 2). The density was determined according to Cain and Castro's scale (1959), where grades were attributed for each species (Table 3). The abundance was evaluated based on an adaptation in Maltzew's scale used by Carvalho and Pitelli (1992), where: U
- species found only once in the whole field $(<1 \%)$; $\mathrm{R}$ - specie rarely found and unnoticed in the crop (1.1-10\%); Sol - species eventually found in the crop (10.1-20\%); Sp - species found in relative abundance, but without apparent overlap on crop (20.1-30\%); Cop - species widely distributed and in some cases suppressing the crop (>30\%).

Table 2. Frequency classes proposed by Raunkiaer (1934).

\begin{tabular}{cccccc}
\hline & \multicolumn{5}{c}{ Class } \\
\cline { 2 - 6 } & A & B & C & D & E \\
\hline Frequency $^{1}$ & $0.01-0.2$ & $0.21-0.40$ & $0.41-0.60$ & $0.61-0.80$ & $0,81-1,0$ \\
\hline${ }^{1}$ Frequencies with values less than 0.01 are not provided in the table above, constituting rare or little representative species.
\end{tabular}


Table 3. Grades density (plant $\mathrm{m}^{-2}$ ) according to Cain and Castro (1959).

\begin{tabular}{cccccc}
\hline & \multicolumn{5}{c}{ Grades } \\
\cline { 2 - 6 } & 1 & 2 & 3 & 4 & 5 \\
\hline Density & $1-4$ & $5-14$ & $15-29$ & $30-99$ & $>100$ \\
\hline
\end{tabular}

\section{RESULTS AND DISCUSSION}

From the analysis of variance, there was significant effect of soil preparation (SP), at 5\% probability, only to dry mass of weeds (DMW) and dry mass of millet (DMM). Already nitrogen fertilization (NF) influenced the parameters total number of weeds (TN) and dry matter of millet. With respect to NF $x$ SP interaction, significant differences were obtained only for DMM (Tables 4 and 5).

Table 4. Number of species (NS), total number and dry mass of weeds (TN and DMW, respectively) according to different soil managements in millet. Aquidauana, MS, 2013.

\begin{tabular}{|c|c|c|c|}
\hline \multirow[t]{2}{*}{ Treatment } & NS & $\mathrm{TN}$ & DMW \\
\hline & \multicolumn{2}{|c|}{------------( $\left(\mathrm{g} \mathrm{m}^{-2}\right)$------------ } & ------( $\left(\mathrm{g} \mathrm{m}^{-2}\right)-----$ \\
\hline \multicolumn{4}{|l|}{ Soil preparation $(\mathrm{SP})$} \\
\hline No-tillage & $6.00 \mathrm{a}$ & $648.50 \mathrm{a}$ & $192.80 \mathrm{a}$ \\
\hline Minimum tillage & $4.13 \mathrm{a}$ & $331.00 \mathrm{a}$ & $69.73 \mathrm{~b}$ \\
\hline Average & 5.07 & 489.75 & 130.97 \\
\hline $\mathrm{F}$ & $4.86^{\mathrm{ns}}$ & $5.09^{\mathrm{ns}}$ & $11.05^{*}$ \\
\hline LSD & 2.71 & 447.59 & 117.74 \\
\hline \multicolumn{4}{|l|}{ Fertilization (NF) } \\
\hline Without nitrogen & $5.75 \mathrm{a}$ & $661.00 \mathrm{a}$ & $150.27 \mathrm{a}$ \\
\hline With nitrogen & $4.38 \mathrm{a}$ & $318.50 \mathrm{~b}$ & $112.25 \mathrm{a}$ \\
\hline Average & 5.07 & 489.75 & 131.26 \\
\hline $\mathrm{F}$ & $1.94^{\mathrm{ns}}$ & $11.80^{*}$ & $1.68^{\mathrm{ns}}$ \\
\hline LSD & 2.42 & 224.26 & 71.86 \\
\hline $\mathrm{F}(\mathrm{SP} \times \mathrm{F})$ & $1.94^{\mathrm{ns}}$ & $0.15^{\mathrm{ns}}$ & $4.20^{\mathrm{ns}}$ \\
\hline CV SP (\%) & 33.61 & 57.48 & 56.41 \\
\hline CV NF (\%) & 38.99 & 40.71 & 44.69 \\
\hline
\end{tabular}

* and **: Significant at 5 and $1 \%$ probability, respectively. ${ }^{\text {ns. }}$ :Not significant.

Table 5. Dry mass production of millet (DMM) according to the soil preparation $\mathrm{x}$ fertilization interaction. Aquidauana, MS, 2013.

\begin{tabular}{cccc}
\hline & \multicolumn{2}{c}{$\mathrm{DMM}\left(\mathrm{g} \mathrm{m}^{-2}\right)$} & \\
\cline { 2 - 4 } Soil preparation $(\mathrm{SP})$ & $0 \mathrm{~N}$ & $50 \mathrm{~kg} \mathrm{ha}^{-1}$ & Average \\
\hline No-tillage & $55.76 \mathrm{bA}$ & $204.87 \mathrm{aA}$ & 130.31 \\
Minimum tillage & $936.50 \mathrm{aA}$ & $217.77 \mathrm{aB}$ & 577.13 \\
\hline Average & 496.13 & 211.32 & 353.72 \\
\hline
\end{tabular}

Averages followed by the same letter in the column and capitalized in the line do not differ by t-test at $5 \%$ level of probability.

For the number of species there were no significant differences in all treatments. Already the total number of weeds differed only in the fertilization; where without nitrogen fertilization resulted in a higher total number of weeds. These results corroborate with Okafor and Zitta (1991) that observed that the soil's nitrogen level influenced the competitiveness of weeds with the main crop.

Theisen et al. (2000) found in bare soils a greater B. plantaginea incidence compared to soil 
with cover, as it the vegetal cover provides a reduction of quantity and modification of light quality that affects the seeds this species. It was expected that the minimum tillage would provide higher values for NS and TN, because according to Vincensi et al. (2011) the soil surface discovered receives more light and have higher temperature amplitude, stimulating the germination of many species, which was not observed in this study. This possibly occurred because the nitrogen fertilization cause a further growth of shoots of millet, generating weed suppression due to increased absorption of light, water and nutrients by millet.

The nitrogen fertilization did not influence the dry mass of weeds. However, the no-tillage system provided greater DMW, differing from the results obtained by Vidal and Trezzi (2004) and Vincensi et al. (2011) that observed in areas with vegetation cover a reduction in the incidence and total dry mass of weeds compared to bare soil.

The dry mass of millet showed significant $F$ $x$ SP interaction, where the minimum tillage without nitrogen fertilization resulted in the highest production of DMM (Table 5). Already nitrogen fertilization of $50 \mathrm{~kg} \mathrm{ha}^{-1}$ associated with soil preparation had no effect on dry mass of millet.

It was observed also that the treatments that resulted in the largest DMM were found a lowest dry mass of weeds. This can be explained due to higher dry mass production of millet probably is associated with greater plant height which, in turn, establishes greater shading, preventing or hindering the germination and growth of some weed species. Kuva et al. (2000) report that at beginning of shading between lines by the sugarcane, there was a reduction in purple nutsedge (Cyperus rotundus) caused by mortality of epigean manifestations and paralysis in the budburst of tubers.

In the phytosociological survey conducted over whole area were identified 21 weed species, grouped into 13 families, revealing heterogeneity of weed community (Table 6). According to Albuquerque et al. (2013) and Zanuncio et al. (2013) the identification of weed species present in no-tillage and minimum tillage systems is an important practice to minimize the difficulty in control, due to features of the plant itself or due to infestation intensity.

Table 6. Scientific name, common name and family of weed species identified in the phytosociological survey conducted in millet under different soil managements. Aquidauana, MS, 2013.

\begin{tabular}{ccc}
\hline & Scientific name & Family \\
\hline \multirow{3}{*}{ No-tillage } & Cynodon dactylon & Poaceae \\
& Commelina benghalensis & Commelinaceae \\
& Cyperus rotundus & Cyperaceae \\
& Stellaria media & Caryophyllaceae \\
& Brassica rapa & Brassicaceae \\
& Mollugo verticillata & Molluginaceae \\
& Galinsoga parviflora & Asteraceae \\
& Sida cordifolia & Malvaceae \\
& Ipomoea grandifolia & Convolvulaceae \\
& Brainvillea rhomboidea & Asteraceae \\
Artemisia verlotorum & Asteraceae \\
Galinsoga quadrirandiata & Asteraceae \\
Bidens pilosa & Asteraceae \\
& Conyza bonariensis & Asteraceae \\
\hline Cynodon dactylon & Poaceae \\
& Commelina benghalensis & Commelinaceae \\
& Cyperus rotundus & Cyperaceae \\
& Stellaria media & Caryophyllaceae \\
& Galinsoga parviflora & Asteraceae \\
& Paspalum maritimum & Poaceae \\
& Euphorbia heterophylla & Euphorbiaceae \\
& Cenchrus echinatus & Poaceae \\
Galinsoga parviflora & Asteraceae \\
& & Asteraceae \\
\hline
\end{tabular}

Minimum tillage
Commelina benghalensis Cleome affinis




\begin{tabular}{|c|c|c|}
\hline \multirow[t]{3}{*}{$0 \mathrm{~N}$} & $\begin{array}{l}\text { Phyllanthus tenellus } \\
\text { Brassica rapa } \\
\text { Paspalum maritimum } \\
\text { Mollugo verticillata }\end{array}$ & $\begin{array}{l}\text { Phyllantaceae } \\
\text { Brassicaceae } \\
\text { Poaceae } \\
\text { Molluginaceae }\end{array}$ \\
\hline & Galinsoga parviflora & Asteraceae \\
\hline & $\begin{array}{c}\text { Acanthospermum hispidum } \\
\text { Crotalaria incana } \\
\text { Euphorbia heterophylla } \\
\text { Bidens pilosa } \\
\text { Conyza bonariensis }\end{array}$ & $\begin{array}{c}\text { Asteraceae } \\
\text { Papilionoideae } \\
\text { Euphorbiaceae } \\
\text { Asteraceae } \\
\text { Asteraceae }\end{array}$ \\
\hline $50 \mathrm{~kg} \mathrm{ha}^{-1}$ & $\begin{array}{c}\text { Cynodon dactylon } \\
\text { Commelina benghalensis } \\
\text { Brassica rapa } \\
\text { Euphorbia heterophylla }\end{array}$ & $\begin{array}{c}\text { Poaceae } \\
\text { Commelinaceae } \\
\text { Brassicaceae } \\
\text { Euphorbiaceae }\end{array}$ \\
\hline
\end{tabular}

The families Asteraceae and Poaceae were those which are most representative species on area (Figure 1), corroborating the results of Pereira and
Velini (2003) and Lima Filho et al. (2004), where the Poaceae family was the most predominant.

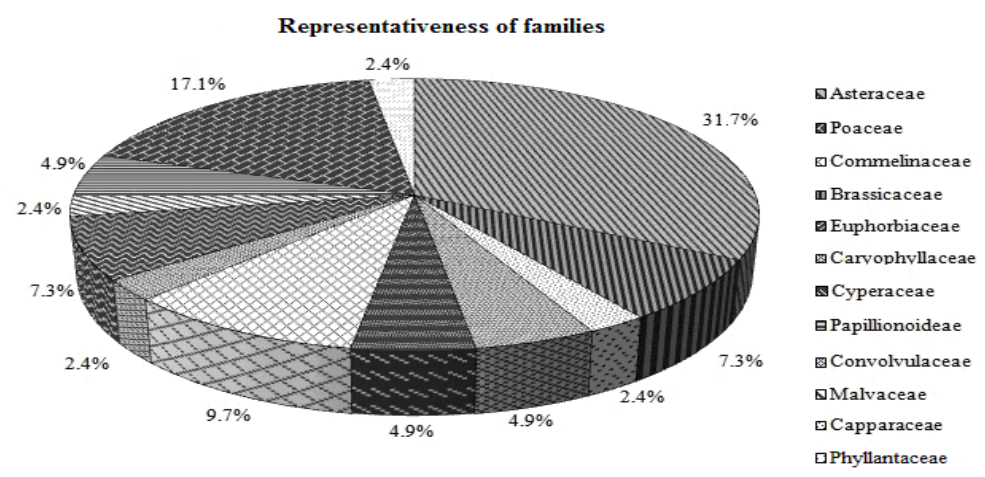

Figure 1. Representativeness of families obtained in relation to number of identified species in millet under different soil managements. Aquidauana, MS, 2013.

Regarding to soil preparation systems were identified in no-tillage 17 species, of which nine belonging to these botanical families. Albuquerque et al. (2012), evaluating the occurrence of weeds after maize crop, found in no-tillage a smaller number of weeds, with 15 species in 9 botanical families.

In minimum tillage, among the 13 identified species, four belonged to Asteraceae family, and only two in the Poaceae, same number of representatives to the Brassicaceae and Euphorbiaceae families (Figure 1). However, despite the greater number of species found in millet belong to the Asteraceae family, when considering the number of individuals, this family had importance was of the same magnitude order of the Commelinaceae family, which only a single species representative (Commelina benghalensis) presented 629 weeds. The family with the largest number of individuals was Poaceae, with 918 plants distributed in three families, probably due to the competition capacity of these plants.

Through phytosociological studies also comes to be possible the knowledge of species interrelationships in space and time, possible to assess the vegetation composition using frequency, density, abundance and Importance Value of species data (PINOTTI et al., 2010; ALBUQUERQUE et al., 2013; CARDOSO et al., 2013).

Overall, the results show low frequency of plants found in samples and the existence of a high heterogeneity in relation to density and abundance, with three species considered highly dense and abundant on area (Cynodon dactylon, Commelina benghalensis and Stellaria media). Cyperus rotundus and Paspalum maritimum shown to be moderately dense and abundant, and the other species had low values for these variables (Table 7). 
Table 7. Scientific names, number of individuals (NI), frequency (F) and frequency class, density (D) and grades density, abundance (A) and abundance class of weeds in millet under different soil managements. Aquidauana, MS, 2013.

\begin{tabular}{cccccccc}
\hline \multirow{2}{*}{ Scientific names } & $\mathrm{NI}$ & \multicolumn{2}{c}{ Frequency } & \multicolumn{2}{c}{ Density } & \multicolumn{2}{c}{ Abundance } \\
\cline { 3 - 8 } & & $\mathrm{F}$ & Class & $\mathrm{D}$ & Grade & $\mathrm{A}$ & Class \\
\hline C. benghalensis & 629 & 0,9 & $\mathrm{E}$ & 157,25 & 5 & 41,93 & Cop \\
C. dactylon & 845 & 0,81 & $\mathrm{E}$ & 211,25 & 5 & 65,00 & Cop \\
E. heterophylla & 68 & 0,5 & $\mathrm{C}$ & 18,75 & 3 & 9,38 & $\mathrm{R}$ \\
S. media & 142 & 0,38 & $\mathrm{~B}$ & 35,5 & 4 & 23,67 & $\mathrm{Sp}$ \\
C. rotundus & 103 & 0,38 & $\mathrm{~B}$ & 25,75 & 3 & 17,17 & $\mathrm{Sol}$ \\
B. pilosa & 9 & 0,25 & $\mathrm{~B}$ & 2,25 & 1 & 2,25 & $\mathrm{R}$ \\
B. rapa & 19 & 0,19 & $\mathrm{~A}$ & 4,75 & 1 & 6,33 & $\mathrm{R}$ \\
P. maritimum & 61 & 0,19 & $\mathrm{~A}$ & 15,25 & 3 & 20,33 & $\mathrm{Sp}$ \\
C. affinis & 12 & 0,19 & $\mathrm{~A}$ & 3 & 1 & 4 & $\mathrm{R}$ \\
G. parviflora & 12 & 0,19 & $\mathrm{~A}$ & 3 & 1 & 4 & $\mathrm{R}$ \\
P. tenellus & 9 & 0,13 & $\mathrm{~A}$ & 2,25 & 1 & 4,5 & $\mathrm{R}$ \\
M. verticillata & 6 & 0,13 & $\mathrm{~A}$ & 1,5 & 1 & 3 & $\mathrm{R}$ \\
C. incana & 5 & 0,13 & $\mathrm{~A}$ & 1,25 & 1 & 2,5 & $\mathrm{R}$ \\
C. bonariensis & 5 & 0,13 & $\mathrm{~A}$ & 1,25 & 1 & 2,5 & $\mathrm{R}$ \\
G. parviflora & 2 & 0,13 & $\mathrm{~A}$ & 0,5 & - & 1 & $\mathrm{U}$ \\
C. echinatus & 12 & 0,06 & $\mathrm{~A}$ & 3 & 1 & 12 & $\mathrm{Sol}$ \\
B. rhomboidea & 2 & 0,06 & $\mathrm{~A}$ & 0,5 & - & 2 & $\mathrm{R}$ \\
A. verlotorum & 2 & 0,06 & $\mathrm{~A}$ & 0,5 & - & 2 & $\mathrm{R}$ \\
I. grandifolia & 2 & 0,06 & $\mathrm{~A}$ & 0,50 & - & 2 & $\mathrm{R}$ \\
S. cordifolia & 2 & 0,06 & $\mathrm{~A}$ & 0,75 & - & 0,19 & $\mathrm{U}$ \\
A. hispidum & 2 & 0,06 & $\mathrm{~A}$ & 0,5 & - & 2 & $\mathrm{R}$ \\
\hline
\end{tabular}

The species $C$. dactylon and C. benghalensis showed the highest frequency, being present in 87 and $94 \%$ of samples, respectively. These species also showed abundance greater than $30 \%$, indicating that these are in thick woods on field, being necessary special attention in its control method. The same is suggested for the species Stellaria media and Paspalum maritimum, because at times when these weeds were found on area, the sample contained between 20 and $24 \%$ of the plants.
According to Albuquerque et al. (2013), a way to assess the real importance of a particular weed inside an agricultural ecosystem is through of the Importance Value rate (IV). Cynodon dactylon is considered the most important weed with IV of $118 \%$ (Figure 2). Similar results were obtained by Cardoso et al. (2013), which evaluated weeds collected at 35 days after sowing of cassava (Manihot esculenta Crantz) in the State of Bahia, found for C. dactylon an IV of $113 \%$.

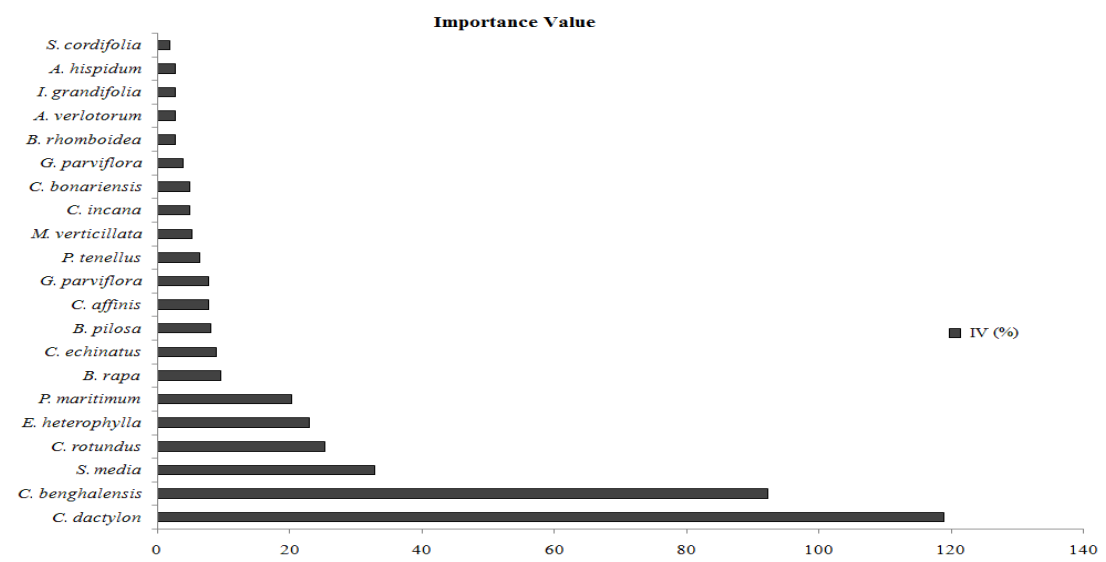

Figure 2. Importance Value (IV) of weeds on millet under different soil managements. Aquidauana, MS, 2013. 
Also according to Albuquerque et al. (2013), the aforementioned species presented high values of the evaluated characteristics, probably due to their underground reproductive structures that enable their growth recovery in a few days.

C. benghalensis also has great importance with IV of $92 \%$, and should be same considered in management strategy. Despite the Asteraceae family pose the greatest number of weed species on area, the species this family showed IV less than $10 \%$. Already the Poaceae family has as representative the species with the highest Importance Value rate, indicating the need of specific management for species this botanical family.

\section{CONCLUSIONS}

The no-tillage provided greater dry mass of weeds, while nitrogen fertilization resulted in a smaller total number of weeds (TN).

The predominant species on area were Cynodon dactylon and Commelina benghalensis that showed a high importance provided by extreme values of density and abundance, indicating that these species require specific management for its suppression.

RESUMO: O cultivo do milheto vem apresentando nas últimas décadas um crescimento da área plantada, sobretudo na região do Cerrado. Entretanto, são escassos os estudos relacionados ao manejo e à fitossociologia de plantas daninhas nesta cultura. Diante disto, o objetivo desta pesquisa foi realizar um levantamento fitossociológico em milheto sob diferentes manejos do solo na região do Cerrado sul-mato-grossense. O experimento foi instalado no setor de Fitotecnia da Universidade Estadual de Mato Grosso do Sul, Unidade Universitária de Aquidauana (UEMS/UUA), município de Aquidauana-MS. A área é cultivada a cinco anos com soja em primeira safra e milho em segunda. O delineamento experimental utilizado foi o de blocos casualizados em esquema de parcelas subdivididas, constituído por quatro blocos e quatro repetições. Nas parcelas foram avaliados os sistemas de preparo do solo (cultivo mínimo e plantio direto) e nas subparcelas a adubação nitrogenada de $50 \mathrm{~kg} \mathrm{ha}^{-1}$ e a ausência de nitrogênio em cobertura no milheto aos 25 dias após a emergência (DAE). Foram avaliados os parâmetros número de espécies (NE), massa seca e número total de plantas daninhas (MSPD e NT, respectivamente), massa seca do milheto (MSM) e frequência (F), densidade (D), abundância (A) e Valor de Importância (IV) das espécies de plantas daninhas. O sistema de plantio direto proporcionou uma maior massa seca de plantas daninhas, enquanto que a adubação nitrogenada conferiu um menor número total de plantas invasoras. Cynodon dactylon e Commelina benghalensis foram as espécies mais predominantes na área.

PALAVRAS-CHAVE: Adubação nitrogenada. Pennisetum glaucum L. Preparo do solo. Identificação de plantas daninhas.

\section{REFERENCES}

ALBUQUERQUE, J. A. A.; MELO, V. F.; SIQUEIRA, R. H. S.; MARTINS, S. A.; FINOTO, E. L.; SEDIYAMA, T.; SILVA, A. A. Ocorrência de plantas daninhas após cultivo de milho na savana amazônica. Planta Daninha, Viçosa, v. 30, n. 4, p. 775-782, 2012.

ALBUQUERQUE, J. A. A.; MELO, V. F.; SOARES, M. B. B.; FINOTO, E. L.; SIQUEIRA, R. H. S.; MARTINS, S. A. Fitossociologia e características morfológicas de plantas daninhas após cultivo de milho em plantio convencional no cerrado de Roraima. Revista Agro@mbiente, Boa Vista, v. 7, n. 3, p. 313-321, 2013.

AZEVÊDO, C. L. L.; CARVALHO, J. E. B.; LOPES, L. C.; ARAUJO, A. M. A. Levantamento de plantas daninhas na cultura da mandioca, em um ecossistema semi-árido do Estado da Bahia. Magistra, Cruz das Almas, v. 12, n. 1/2, p. 41-49, 2000.

BRAUN-BLANQUET, V. Fitosociología, bases para el estudio de las comunidades vegetales. Madrid: H. Blume, 1979. $820 \mathrm{p}$.

BULEGON, L. G.; CASTAGNARA, D. D.; BERTÉ, L. N.; OLIVEIRA, P. S. R. NERES, M. A. Efeito do consórcio de milho com Braquiaria brizantha em diferentes taxas de semeadura sobre a incidência de ervas daninhas. Revista Cultivando o Saber, Cascavel, v. 5, n. 4, p. 72-86, 2012. 
CAIN, S. A.; CASTRO, G. M. Manual of vegetation analysis. New York: Hafner Publishing Company, 1959. $325 \mathrm{p}$.

CARDOSO, A. D.; VIANA, A. E. S.; BARBOSA, R. P.; TEIXEIRA, P. R. G.; CARDOSO JÚNIOR, N. S.; FOGAÇA, J. J. N. L. Levantamento fitossociológico de plantas daninhas na cultura da mandioca em Vitória da Conquista, Bahia. Bioscience Journal, Uberlândia, v. 29, n. 5, p. 1130-1140, 2013.

CARVALHO, S. L.; PITELLI, R. A. Levantamento e análise fitossociológica das principais espécies de plantas daninhas de pastagens da região de Selvíria (MS). Planta Daninha, Viçosa, v. 10, n. 1, p. 25-32. 1992.

EMBRAPA. Sistema brasileiro de classificação de solos. 3. ed. Rio de Janeiro: Centro Nacional de Pesquisa de Solos, 2013. 306 p.

FERREIRA, D. F. Sisvar: a computer statistical analysis system. Ciência e Agrotecnologia (UFLA), Lavras, v. 35, n. 6, p. 1039-1042, 2011.

GODOY, G.; VEGA, J.; PITTY, A. El tipo de labranza afecta la flora y la distribución vertical del banco de semillas de malezas. Ceiba, Tegucigalpa, v. 36, n. 2, p. 217-229, 1995.

GUGLIERI-CAPORAL, A.; CAPORAL, F. J. M.; POTT, A. Phytosociology of sown pasture weeds under two levels of degradation in Brazilian savanna areas, Mato Grosso do Sul State, Brazil. Pesquisa Agropecuária Tropical, Goiânia, v. 40, n. 3, p. 312-321, 2010.

GUGLIERI-CAPORAL, A., CAPORAL, F. J. M., VINCI-CARLOS, H. C., PINTO, B. E. de M. Fitossociologia de plantas espontâneas em um mandiocal implantado em pastagem cultivada em Mato Grosso do Sul, Brasil. Revista Ciência Agrária, Belém, n. 51, p. 127-141, 2009.

JAKELAITIS, A.; FERREIRA, L. R.; SILVA, A. A.; AGNES, E. L.; MIRANDA, G. V.; MACHADO, A. F. L. Dinâmica populacional de plantas daninhas sob diferentes sistemas de manejo nas culturas de milho e feijão.

Planta Daninha, Viçosa, v. 21, n. 1, p. 71-79, 2003.

KUVA, M. A.; PITTELI, R. A.; CHRISTOFFOLETI, P. J.; ALVES, P. L. C. A. Períodos de interferência das plantas daninhas na cultura da cana-de-açúcar. I - Tiririca. Planta Daninha, Viçosa, v. 18, n. 2, 2000.

LIMA FILHO, D. A.; REVILLA, J.; AMARAL, I. L.; MATOS, F. D. A.; COÊLHO, L. S.; RAMOS, J. F.; SILVA, G. B.; GUEDES, J. O. Aspectos florísticos de 13 hectares da área de Cachoeira Porteira-PA. Acta Amazônica, Manaus, v. 34, n. 3, p. 415-423, 2004. http://dx.doi.org/10.1590/S0044-59672004000300007

OKAFOR, L. I.; ZITTA, C. The influence of nitrogen on sorghum-weed competition in the tropics. Tropical Pest Management, London, v. 37, n. 2, p.138-143, 1991. http://dx.doi.org/10.1080/09670879109371561

OLIVEIRA, A. R.; FREITAS, S. P. Levantamento fitossociológico de plantas daninhas em áreas de produção de cana-de-açúcar. Planta Daninha,Viçosa, v. 26, n. 1, p. 33-46, 2008.

PEREIRA, F. A. R.; VELINI, E. D. Sistema de cultivo no cerrado e dinâmica de população de plantas daninhas. Planta Daninha, Viçosa, v. 21, n. 3, p. 355-363, 2003.

PEREIRA-FILHO, I. A.; FERREIRA, A. S.; COELHO, A. M.; CASELA, C. R.; KARAN, D.; RODRIGUES, J. A. S.; CRUZ, J. A.; WAQUIL, J. M. Manejo da cultura do milheto. Embrapa Milho e Sorgo, 17 p. 2003. Circular Técnica 29.

PINOTTI, E. B.; BICUDO, S. J., CURCELLI, F.; DOURADO, W. de S. Levantamento florístico de plantas daninhas na cultura da mandioca no município de Pompéia - SP. Revista Raízes e Amidos Tropicais, Botucatu, v. 6, p. 120-125, 2010. 
RAUNKIAER, C. The life forms of plants and statistical plant geographyaphy. Oxford, Clarendon. 632p, 1934.

THEISEN, G.; VIDAL, R. A.; FLECK, N. G. Redução da infestação de Brachiaria plantaginea em soja pela cobertura do solo com palha de aveia preta. Pesquisa Agropecuária Brasileira, Brasília, v.35, p.753-756, 2000. http://dx.doi.org/10.1590/S0100-204X2000000400011

TORRES, F. E.; SILVA, E. C.; TEODORO, P. E.; Desempenho de genótipos de soja nas condições edafoclimáticas do ecótono Cerrado-Pantanal. Interações, Campo Grande, v. 15, n. 1, p. 71-78, jan./jun. 2014. http://dx.doi.org/10.1590/S1518-70122014000100007

VIDAL, R. A.; TREZZI, M. M. Potencial da utilização de coberturas vegetais de sorgo e milheto na supressão de plantas daninhas em condição de campo: I - plantas em desenvolvimento vegetativo. Planta Daninha, Viçosa, v. 22, n. 2, p. 217-233, 2004. http://dx.doi.org/10.1590/s0100-83582004000200007

VINCENSI, M. M.; ARAÚJO, E. O; KIKUTI, H. Manejo do solo e adubação nitrogenada na supressão de plantas daninhas na cultura do feijão de inverno e irrigado. Revista Ciência Agronômica, Fortaleza, v. 42, n. 3, p. 758-764, 2011. http://dx.doi.org/10.1590/S1806-66902011000300023

ZANUNCIO, A.; TEODORO, P. E.; RIBEIRO, L. P.; CORREA, C. C. G.; OLIVEIRA, M. A.; TORRES, F. E. Alelopatia de adubos verdes sobre Cyperus rotundus. Revista de Ciências Agrárias, Lisboa, v. 36, p. 441-446, 2013. 